\title{
Educational Supervisors Practice level of the Three Dimensions Leadership Theory In E6ry Estate in Sutanate Oman
}

\section{Dr. Mohamed Suliman Algaraidih}

Associate professor of educational administration,

Nizwa University, Oman

\section{Abstract:}

his study aimed at recognizing the
Educational Supervisors Practice level of the
leadership Three Dimensions Theory in Ebry estate in Sutanate Oman. For achieving this aim a written questionnaire was categorized into three dimensions (task efficacy - relations), After assuring its reliability and validity, the questionnaire was applied on 50 senior teachers in 2020/2021. The study findings showed that Educational Supervisors Practice level of the leadership three dimensions Theory in Ebry estate in Sultanate Oman was average. Findings also showed no significant statistical differences in Educational Supervisors Practice level of the Leadership Three Dimensions Theory in Ebry in Sultanate Oman at 0.05 level. This may be a result of variables such as ( social pattern and qualifications). In the light of these findings, the researchers recommended reinforcing the teachers role in taking decisions related to the educational process by imposing educational supervisors to consider teachers opinions during the supervision visits and pay their attention to the old experienced teachers to make use of their experience or to improve their performance, to encourage them to cooperate with novice teachers, and to encourage supervisors to offer advices to teachers and try to increase level of cooperation between teachers and supervisors.

Keywords : Educational Supervisors - Practice level Three Dimensions Leadership Theory - Ebry Estate Sutanate Oman

\section{Introduction:}

Educational supervision is considered the backbone of the educational process in developing the educational and 
learning system in all its fields to improve the educational practices of teachers and consequently to provide distinguished education and to raise its efficacy level. The role of the educational supervisor was obviously developed to be a leader who can influence the teachers' performance by urging them to be creative and to encourage them to use the independent thinking strategies, solve the points of difference, share tasks and duties and evaluate results.

The educational supervisor performs some leadership supervision processes when working with leaders seeking to offer suitable intellectual, psychological and financial atmosphere to reinforce and encourage them to work in an organized and active group work so as to overcome difficulties, to solve problems and challenges in the work environment and to achieve the prescribed aims of the community as well as the educational institutions (Alfryhat, 2016).

The leadership supervisory behavior based on the three dimensions in leadership is characterized by encouraging teachers to effectively and professionally perform their mission and their duties for reaching a high level of productivity and the highest level of achievement and lay challenging objectives to be accurately performed and give them a high degree of self confidence in confronting challenges that might face those performing untraditional routine vague tasks. The educational supervisory behavior here is concerned with developing and increasing teachers explanations that their roles and mission will contribute to achieving the expected performance (Devany, 2013) 
The three dimensions theory of Reddin is considered one of the recent theories that is broadly accepted in the work field as it contains three dimensions : (task dimension) which means the educational supervisors perception of the extent to which they can cooperate with teachers to achieve the aims. ( The Relations Dimension) which means the educational supervisors ability to form personal work relations that are characterized by mutual confidence and respect of others' opinions, ideas and feelings. (The efficacy dimension) which means the educational supervisor's perception of the extent to which he will achieve the educational aims, whether they are effective or not.

Reddin explained that situations have effective factors that reflect the school organizational efficacy. Among these is the psychological atmosphere in the classroom environment and the technology used in carrying out the supervisory practices, the relations among supervisors, educationalists and teachers (Kanaan,2010). The three dimensions theory involve four ways of leadership: a separate way which means a little concern with the task and a little concern with the relations, and an integrated way which means a little concern with the task and a high concern with the relations, devotion technique which means a high concern with the task and a little concern with the relations, an integrated way which means a high concern with both task and relations 
The effective educational supervisor is one who chooses a leading supervisory type that has positive general effect on the classroom and on the mood of teachers, students and their learning, and on the overall performance of the educational institutions as the effective leading educational supervisors are the creative people who reinforce teachers to do creative ideas to achieve the educational and learning process objectives using their personal characters and their social talents and make available some kind of satisfaction and self esteem to support teachers to achieve personal esteem and give them the chance to develop their abilities, satisfy their needs, desires and reach to a fruitful cooperation and harmony in doing the prescribed tasks (Alfrihat 2012).

The three dimensions theory emphasizes that educational supervisors should pay more attention to the two dimensions of productivity and humanity as both represent the way through which the educational supervisors deal with teachers and which are considered the main factors behind the success or failure of the educational process. This because the educational supervisor has a decisive role in affecting the teachers behavior and provides suitable and effective environmental and scientific atmosphere.

\section{The Problem of the Study and Questions:}

Various studies showed that the educational supervisor is considered an educational leader who uses the power of his personality to influence the teacher in a way that 
achieves the prescribed educational aims. This necessitates that the educational supervisor uses new techniques of supervision to achieve the professional needs of teachers and get rid of difficulties that reduce the effect of educational supervisor on teachers professional development.

However, the educational reality shows that most supervision practices mostly depend and focus on the strategy of class supervision visits as the basic way used by the educational supervisor during his supervision visits that mostly seeks to find out faults and drawbacks ( Al Ghafry, 2012) This requires that educational supervisors use more recent supervisory ways that are still not given enough practice such as the supervision that is based on recent effective leadership theories such as generative leadership, the transformation leadership, interchangeable leadership, service leadership, and the three dimension leadership. This study aimed at recognizing the level in which the educational supervisors practice using the three dimensions theory in Ebry estate in Sultanate Oman

\section{Questions of the study}

- What's the level of the educational supervisors use of the three dimensions theory in leadership in Ebry estate in Sultanate Oman?

- Does the degree of educational supervisors use of the three dimensions theory of leadership differ according to the variables of social pattern and qualifications? 


\section{Aims of the Study:}

This study aims to achieve the following:

- To identify the leadership techniques used by the educational supervisors in Ebry Estate in Sultanate Oman according to the leadership three dimensions theory.

- To identify the educational supervisors practice level of using Reddin's leadership three dimensions theory in Ebry Estate in Sultanate Oman ( mission- production relations ).

- To identify the significance of differences between the degree of the educational supervisors' practice of the three dimensions theory in leadership in Ebry estate in Sultanate Oman and which are due to the variables of the study.

- To present suggestions and recommendations to support the leadership role of the educational supervisors in Ebry estate in Oman.

\section{Significance of the Study:}

Educational research proved the significance of the leadership types of the educational supervisors as being leaders in the educational field.

Specifically the significance of the study can be clarified in the following:

The study was expected to offer feedback to educational supervisors about the level of their practice of effective leadership types according to the three dimensions theory 
in leadership as this will contribute to reforming the weak points and reinforcing the strong ones.

The study was expected to add cognitive knowledge to the Arab library and to have reflections on the field of education. This study might be a basis to other studies about the leadership types of educational supervision according to the other leadership theories

What adds to the significance of the study is that the studies related to this field are rare ( according to the researcher's knowledge)

The study can also add a specific significance to the training programs of educational supervisors through focusing on the leadership type as it still needs more practice.

\section{Definition of Terms:}

The study used the following terms:

- Practice: A group of administrative tasks that educational supervisors do in Ebry estate in Sultanate Oman and that can be measured through the three categories of the questionnaire ( task -efficacy - and relations )

- Three Dimensions Theory: a three dimensions theory suggested by William Reddin and consists of three dimensions related to leadership behavior analysis and includes the task dimension, the relations dimension and the efficacy dimension. 


\section{Limitations of the study:}

- Results of this study were limited to"

- Topic limits, The study includes three main dimensions (task - efficacy - and relations

- Place limits: The study is limited to the training schools in Oman

- Human limits: The study was conducted in 2020/2021

- Study limits: The level of the participants accuracy, validity and objectivity in responding to the questionnaire

\section{PREVIOUS STUDIES:}

Through reviewing previous studies ( according to the researchers' knowledge ) there were no single study in Oman that has any direct relation to the present study, However there are some Arabic and foreign studies that are somewhat related to the field of the present study.

The study conducted by Al Helw (2009) aimed at recognizing the degree that educational supervisors practice supervisory types in Palestinian secondary schools. The study was conducted on a sample of (565) male and female teachers. A questionnaire was conducted to measure the types of supervision. Results showed that the degree of practice was average.

Besides, there were statistical significant differences among the supervision types. Similarly, there were significant differences between males and females in all fields and between highly qualified and low ones and 
between those who have five years experience and those who have experience between 5-10 years or more than 10 years.

Alzaidy (2015) conducted a study that aimed at identifying the nature of the relationship between the behavior of the transformative leadership of the managers of the learning offices in Gedda governorate and the educational confidence of supervisors. To achieve this aim, the field study tried to identify the degree to which those managers practice the transformative leadership behavior and to recognize the level of the organization confidence of the educational supervisors.

The researcher also prepared a questionnaire that was administered to 204 supervisors working at the learning agencies . Results showed that their practice of the transformative leadership behavior was very high and the organization confidence level of educational supervisors was ( strongly agree) and was so in all dimensions of organizational confidence.

The study conducted by Aysh (2012) aimed at identifying the degree of educational supervisors practice using the three dimensions leadership from the point of view of school managers and teachers at Ghoth Agency in Jordan depending on 53 items instrument.

The sample consisted of 80 male and female managers, 200 male and female teachers. The study was conducted through 2009-2010. Results showed that the level of the 
supervisors practice of the three dimensions leadership theory used in carrying out their supervising tasks was average in each of the dimensions and in overall dimensions . Results also showed statistical significant difference between estimates of the teachers and those of school managers in favor of the school managers in all dimensions

Results also showed no significant differences between teachers estimation and those of the managers in the three dimensions in sex. There were also statistical significant differences between managers evacuation and those of the teachers due to sex in the efficacy dimension.( in favor of the females) .

Meskin (2017) conducted a study to recognize the dominant leadership behavior among the educational supervisors in dealing with teachers. The sample consisted of 30 male and female educational supervisors randomly chosen in the school year 2013/2014. To achieve the aims of the study, the researcher used the leadership behavior scale. Reliability and validity were assured. Results showed that

- the mean of the level of the educational supervisors' use of leadership behavior was 91.47 and with standard deviation 5.28. Leadership behavior concerned with work came first followed by leadership behavior related to human relations,

- no significant differences were found in the leadership behavior related to the sex variable. 
The study of El-Enzy (2017) aimed to measure the level the educational supervisors' use of administrative creativity in Riyadh city. To achieve this aim the participants were randomly chosen from among educational supervisors. Their number amounted to 179 supervisors. A (35) item questionnaire was designed. The items were categorized to three dimensions. Results showed that the participants responses were "agree" on the administrative creativity of educational supervisors in Riyadh. The highest practices were on the dimension saying (the educational supervisors help teachers to express their opinions about developing teaching techniques. Response of the participants was ( agree) on the difficulties that hinder the administrative creativity of educational supervisors in Riyadh. Difficulty came first (the administrative load on the supervisors is great followed by ( the educational supervisors participation in programs related to administrative creativity was low).

The study conducted by Rahmi and Ibrahim (2019) aimed to be acquainted with the level of private schools use of Reddin's dimensions and its relation to the creative behavior of teachers in Maskat governorate in Sultanate Oman A questionnaire was used to collect data and was applied on 500 female and male teachers. Results showed that the degree of the three dimensions theory use by the private schools directors in Maskat governorate in Sultanate Oman in all dimensions of the study was within the average degree. 
Results of the study also showed the degree of creative behavior of private school teachers in all dimensions. Results also showed a positive and significant correlation between the degree of Reddin's dimension theory use by private school directors and the creative behavior of teachers in Maskat governorate in Sultanate Oman.

Al Abidani (2020) conducted a study to clarify the educational supervisors use of the transformative leadership and its relation to their educational supervision and the correlation between them. The study followed the analytical descriptive design. The population of the study was chosen from (121) educational supervisors in the academic year 2019/2020. The sample consisted of randomly chosen 85 supervisors . Results showed that the degree of supervisors practice of transformative leadership was average and the arithmetic mean score was 3.47.

Therefore the first dimension ranked first: the ideal effect (3.37) followed by the individual consideration (3.65) and then the intellectual excitability (3.24) and motivation came last (3.24). The mean scores indicated that the educational supervisor does not apply the transformative leadership during the school visits

Summary of the previous studies and their relation to the present study:

\section{FROM THE ABOVE MENTINED STUDIES IT it BECAME CLEAR THAT:}

Most studies used the descriptive design as it is suitable to this kind of research. They also used the questionnaire as the main instrument to collect data . 
There is shortage in studies related to the educational supervisors practices ( in Ebry estate in Sultanate Oman) of an important leadership theory in education and service institutions that affect the community life such as that of schools especially in Sultanate Oman

The present study made use of those previous studies to enrich the theoretical and practical dimensions in building the questionnaire of the study. This helped in designing a good, comprehensive, reliable and valid instrument. The researcher also made use of the findings of these studies and identified the similarities and differences among them.

The present study is different from the previous ones in being an organized and analytical study of the degree and kevel of supervisors' use of the three dimensions theory of leadership in Ebry estate in Sultanate Oman.

\section{Design and Procedure:}

\section{Design:}

The researchers used the survey descriptive design. This design is suitable to the nature of the study and its objectives.

\section{Study Population:}

Study population was formed from the educational supervisors in Ebry estate in Sultanate Oman in the school year 2020/2021.

\section{Instrument:}

The researcher prepared and developed the instrument of the study to measure the degree of educational supervisor's 
use of the three dimensions leadership theory in Sultanate Oman depending on the study of Aysh (2012) which dealt with the leadership topic. The questionnaire had 40 items divided into three main dimensions each of which had a number of items.

\section{Validity of the instrument :}

To emphasize the validity of the instrument, it was judged by (8) staff members who were concerned with the topic of the present study from universities and ministry of education in Sultanate Oman. They were requested to express their view points in the accuracy, stating, and clarity of the items. According to the jury members recommendations some items were modified to suit the field of the study. It included 54 items in its final form. The following table was used to interpret results

Table (1) Interpretation of the findings

\begin{tabular}{|c|c|c|}
\hline Mean & Level of practice & criteria \\
\hline $1-2.33$ & low & $\begin{array}{c}\text { One SD FROM } \\
\text { THE MEAN }\end{array}$ \\
\hline $2.34-3.67$ & average & average \\
\hline $5-3.68$ & high & $\begin{array}{c}\text { One SD from the } \\
\text { average }\end{array}$ \\
\hline
\end{tabular}

The researchers used this table by dividing the total mark (5) into three equal categories from 1 to 5 according to the following formula: The highest value of the response alternative minus the lowest value of the response divided by the number of the three levels ( high- average and low) 
; $1-5$ divided by $3=1.33$. This value equals the range between the three levels ( high- average- low)"

$$
1+1.33=2.33 \quad 2.33+1.33=3,66 \quad 3.66+1.33=5.00
$$

Consequently the means of efficacy that ranges between $1.00-2.33=$ low practice level, 2.34- 3.66 = average level , $3.67-5.00=$ high practice level.

\section{Reliability of the instrument :}

The reliability was emphasized through using Cronbach Alfa of all three dimensions of the study The reliability coefficient was (0.89) and this is accepted.

\section{Validity of the Study Variables}

\section{The Independent variables}

\section{Social TYPE:}

It has two types: males and females

Qualifications: Bsc., high Diploma, and master

\section{The Dependent Variable}

The degree that educational supervisors practice the leadership three dimensions theory in Ebry estate in Sultanate Oman.

\section{The Statistical Treatment}

The SPSS statistical program was used to analyze the questionnaire and the statistical treatment related to the main questions of the study was used as follows:

- To answer the first question, the means, standard deviations and rank were used to measure the kevel of 
educational supervisors' use of the leadership three dimensions theory in Ebry estate in Sultanate Oman

- To answer the second question, t-test was used to calculate the differences between means of the study participants related to the social variables and one way analysis of variance of three independent samples to examine whether there were differences among the mean values of the participants due to the qualification variable.

\section{Results and discussion:}

\section{Results related to the first question}

"THE degree of educational supervisors use of the leadership three dimensions theory in Ebry estate in Oman"

To answer this question, means, standard deviations and rank were calculated.

Table (2) Means, standard deviations and rank of the study's dimensions according to the Arithmetic Means

\begin{tabular}{|c|c|c|c|}
\hline Rank & Dimension & Means & $\begin{array}{c}\text { Standard } \\
\text { deviations }\end{array}$ \\
\hline 1 & Relations & 3.36 & 0.36 \\
\hline 2 & task & 3.31 & 0.53 \\
\hline 3 & Efficacy & 3.45 & 0.95 \\
\hline & Total & 3.37 & 0.75 \\
\hline
\end{tabular}


- It is evident from the previous table that the arithmetic means of the participants response to the questionnaire items ranged from $3.31: 3.54$. The relations dimension came first with a mean (3.36) and a standard deviation (0.36), followed by the task dimension (mean $=3.31$ and $\mathrm{SD}=0.53$ followed by the efficacy dimension ( mean= 3.45, $\mathrm{SD}=0.95$ ).

- The overall mean of all dimensions is ( 3.37) and $\mathrm{SD}=(0.75)$. This refers to the degree that educational supervisors practice the three dimensions theory of leadership. This result may be attributed to the inadequate perception of the educational supervisors roles as leaders in the educational field. This result may also be attributed to the insufficient time to practice the three dimensions (as reflected in their points of view ) due to the great number of teachers in their schools and the various demonstrations and tasks required from them This result may also be due to the birocratic type imposed on the supervisors' practices as they believe that this is the best way to do their work

The means, SD, and ranks of the items of every field are as follows:

\section{Task:}

This field aimed to identify the degree of educational supervisors use of the leadership three dimensions theory in Ebry estate in Oman according to the task dimension. The following table shows the means, SD, and ranks of items according to the task dimension 
Table (3) Means, SD, and ranks of items according to the task dimension

\begin{tabular}{|c|c|c|c|c|}
\hline $\begin{array}{l}\text { No of } \\
\text { items }\end{array}$ & ITEM & MEAN & SD & $\begin{array}{l}\text { Level of } \\
\text { practice }\end{array}$ \\
\hline 1 & $\begin{array}{l}\text { Carries out special supervision } \\
\text { program with novice teachers }\end{array}$ & 3.50 & 0.92 & average \\
\hline 2 & $\begin{array}{l}\text { Document his supervision using by } \\
\text { using scientific techniques }\end{array}$ & 3.40 & 0.99 & average \\
\hline 3 & $\begin{array}{l}\text { Is keen to offer written feedback to } \\
\text { teachers on their performance }\end{array}$ & 3.25 & 0.99 & average \\
\hline 4 & $\begin{array}{l}\text { presents suggestions to improve the } \\
\text { teaching/learning environment }\end{array}$ & 3.01 & 0.75 & average \\
\hline 5 & $\begin{array}{l}\text { Carries out his training efficacy } \\
\text { cooperatively with teachers }\end{array}$ & 3.85 & 1.13 & average \\
\hline 6 & Depends on preplanned supervision & 3.07 & 1.02 & average \\
\hline 7 & $\begin{array}{l}\text { Encourages directed scenarios among } \\
\text { teachers }\end{array}$ & 3.22 & 1,05 & average \\
\hline 8 & $\begin{array}{l}\text { Identifies difficulties of carrying out } \\
\text { the teachers' tasks }\end{array}$ & 2,86 & 1,09 & average \\
\hline 9 & $\begin{array}{l}\begin{array}{l}\text { Devotes a part of his duties to } \\
\text { teachers }\end{array} \\
\end{array}$ & 3.62 & 0.94 & average \\
\hline 10 & $\begin{array}{l}\text { Pre-plans to his } \\
\text { teachers }\end{array}$ & 3.27 & 0.90 & average \\
\hline 11 & Avoids giving strict instructions & 3.80 & 0.95 & high \\
\hline 12 & $\begin{array}{l}\text { Uses accurate and clear language } \\
\text { when writing rules and instructions }\end{array}$ & 3.29 & 0.99 & average \\
\hline 13 & $\begin{array}{l}\text { Avoids using unreasonable systems } \\
\text { and instructions }\end{array}$ & 3.80 & 0.95 & high \\
\hline 14 & $\begin{array}{l}\text { Uses scientific technique to identify } \\
\text { the training needs of teachers }\end{array}$ & 3.27 & 1.22 & average \\
\hline 15 & $\begin{array}{l}\text { Joins teachers to training programs } \\
\text { according to their needs }\end{array}$ & 3.99 & 1.11 & high \\
\hline 16 & $\begin{array}{l}\text { Adopts new leadership types in } \\
\text { carrying out his supervision tasks }\end{array}$ & 3,26 & 1.14 & average \\
\hline 17 & $\begin{array}{l}\text { Uses new technology in carrying out } \\
\text { his supervision tasks }\end{array}$ & 3.09 & 0.98 & average \\
\hline 18 & $\begin{array}{l}\text { Provides teachers with specialized } \\
\text { educational posters }\end{array}$ & 4.20 & 1,03 & high \\
\hline 19 & $\begin{array}{l}\text { Acknowledge teachers with recent } \\
\text { things in his specialization }\end{array}$ & 4.00 & 0.95 & high \\
\hline 20 & $\begin{array}{l}\text { Cooperates with teachers in planning } \\
\text { his supervision programs }\end{array}$ & 3.29 & 0.99 & average \\
\hline 21 & $\begin{array}{l}\text { Follows teachers to functionalize } \\
\text { educational posters and issues }\end{array}$ & 3.62 & 0.95 & average \\
\hline 22 & $\begin{array}{l}\text { Organize effective programs to } \\
\text { exchange teaching } \\
\text { among teachers }\end{array}$ & 3,30 & 0.98 & average \\
\hline \multicolumn{2}{|c|}{ the overall mean } & 3.36 & 0.36 & average \\
\hline
\end{tabular}


Means of this dimension ranges between (4.20-2.22) and standard deviation between (1.03-1.05) item No.(18) " Provides teachers with specialized educational posters" the highest mean (4.20) and standard deviation (1.03), followed by item (19)" Acknowledge teachers with recent things in his specialization" with a mean (4.00) and standard deviation (1.03). Statistical analysis showed that item (7) has the least mean (2.22) and standard deviation (1.05), item No (8) " Identifies difficulties of carrying out the teachers' tasks" before last with a mean -(2.86) and standard deviation (1.09). Generally, the overall mean related to the task dimension (3.36) and standard deviation (0.36). This indicates that the level of educational supervisors' use of leadership three dimensions theory in Ebry estate in Sultanate Oman was average.

This result may be attributed to the insufficient time to practice the three dimensions (as reflected in their points of view) due to the great number of teachers in their schools and the various demonstrations and tasks required from them and the great number of schools they must supervise. This result may also be due to the birocratic type imposed on the supervisors' practices as they believe that this is the best way to do their work. This result copes with that of Aysh (2012) .

\section{Efficacy}

This dimension aims at identifying the level of educational supervisors' use of leadership three dimensions theory in Ebry estate in sultanate Oman. The following table shows means, standard deviations and level of items according to the efficacy dimension 
Table (4) Means, standard deviations and level of Practice according to the efficacy dimension

\begin{tabular}{|c|c|c|c|c|}
\hline $\begin{array}{l}\text { No. of } \\
\text { items }\end{array}$ & items & mean & SD & $\begin{array}{l}\text { Level of } \\
\text { practice }\end{array}$ \\
\hline 1- & $\begin{array}{l}\text { Directs his supervision towards improving } \\
\text { the outputs of teaching/learning }\end{array}$ & 4.41 & 0.78 & high \\
\hline 2 & $\begin{array}{l}\text { Reinforces teachers and rewards their } \\
\text { achievement. }\end{array}$ & 4.52 & 0.92 & high \\
\hline 3 & Increases the leadership spirit in his teachers & 2,50 & 0.73 & average \\
\hline 4 & $\begin{array}{l}\text { Ignores the minor mistakes and concentrates } \\
\text { on achievement }\end{array}$ & 4.02 & 0.82 & high \\
\hline 5 & $\begin{array}{l}\text { Gives teachers a chance to correct their } \\
\text { teaching mistakes }\end{array}$ & 3.80 & 0.81 & high \\
\hline 6 & $\begin{array}{l}\text { Puts systems and rules to reinforce teachers' } \\
\text { self confidence }\end{array}$ & 1.97 & 1.05 & low \\
\hline 7 & $\begin{array}{l}\text { Is concerned with affective, skillful and } \\
\text { cognitive development of teachers }\end{array}$ & 3,67 & $\mathbf{0 . 8 0}$ & Average \\
\hline 8 & $\begin{array}{l}\text { Follows the professional development of } \\
\text { teachers after finishing the requirements of } \\
\text { the training programs }\end{array}$ & 3,27 & 1.14 & average \\
\hline 9 & $\begin{array}{l}\text { Varies his ways of reinforcing individuals } \\
\text { and groups of teachers }\end{array}$ & 3.14 & 1.17 & average \\
\hline 10 & $\begin{array}{l}\text { Increases teachers awareness of their } \\
\text { different roles }\end{array}$ & 1,99 & 0.95 & low \\
\hline 11 & Has commitment with his teachers & 3.29 & 0.96 & average \\
\hline 12 & Adopts teachers' creative ideas & 3.26 & 1.22 & average \\
\hline 13 & Lets teachers In taking decisions & $\mathbf{3 . 2 3}$ & 1,14 & average \\
\hline 14 & $\begin{array}{l}\text { Makes use of old teachers' experiences in } \\
\text { carrying out his supervision programs }\end{array}$ & 3,99 & 1,14 & high \\
\hline 15 & $\begin{array}{l}\text { Follows teachers' use of the modern } \\
\text { technology }\end{array}$ & 3,09 & 0.98 & average \\
\hline 16 & $\begin{array}{l}\text { Follows the teachers' professional } \\
\text { development when they join the training } \\
\text { programs }\end{array}$ & 2.85 & $\mathbf{0 . 5 0}$ & average \\
\hline 17 & Gives special attention to novice teachers & 2.70 & 0.99 & average \\
\hline 18 & Encourages the effective groups of teachers & 3.66 & 0.75 & average \\
\hline 19 & $\begin{array}{l}\text { Allows teachers to discuss their supervisory } \\
\text { remarks }\end{array}$ & 3.07 & 1.02 & average \\
\hline & The overall mean & $\mathbf{3 , 3 1}$ & 0.53 & average \\
\hline
\end{tabular}

It is clear from the above table that Means of this dimension ranges between (1.97:4.52) and standard 
deviation (1.05 : 0.92) Item No. (2) " Reinforces teachers and rewards their achievement." Has the highest mean (4.52) and standard deviation(0.92), followed by item (1) ' Directs his supervision towards improving the outputs of teaching / learning" with a mean (4.41) and standard deviation (0.78) . Analysis also showed that item (6) " Puts systems and rules to reinforce teachers' self confidence " has the least mean (1.97), and standard deviation (1.05) and item (10) " Increases teachers awareness of their different roles" came before last in rank with a mean (1.99) and standard deviation (0.95) . Generally, the overall mean related to efficacy is (3.31) and standard deviation ( 0.53)

This indicates that the level of educational supervisors use of leadership three dimensions theory in Ebry estate in Sultanate Oman was average in the efficacy dimension. This result may be attributed to the big gap in confidence between educational supervisors and teachers. Educational supervisors have no enough time to follow the professional development of teachers after they finish their training programs .

\section{3-Relations}

This dimension aims at identifying the level of educational supervisors' use of leadership three dimensions theory in Ebry estate in sultanate Oman as related to the relations dimension.

The following table shows means, standard deviations and level of items according to the relations dimension 
Table 5: Means, standard deviations and level of items according to the relations dimension

\begin{tabular}{|c|c|c|c|c|}
\hline $\begin{array}{l}\text { No.of } \\
\text { itms }\end{array}$ & items & mean & SD & $\begin{array}{l}\text { LEVEL OF } \\
\text { PRACTICE }\end{array}$ \\
\hline 1 & \begin{tabular}{|l} 
Provides a democratic social \\
atmosphere to support teachers
\end{tabular} & 3.69 & $\mathbf{0 . 4 0}$ & average \\
\hline 2 & $\begin{array}{l}\text { Assign fixed criteria in dealing } \\
\text { with teachers }\end{array}$ & 3.29 & 0.99 & average \\
\hline 3 & $\begin{array}{l}\text { Differentiates between } \\
\text { relations and personal ones }\end{array}$ & 4.07 & 1.22 & average \\
\hline 4 & $\begin{array}{l}\text { Reinforces teachers' relations } \\
\text { with administrators }\end{array}$ & 3.23 & 1.11 & average \\
\hline 5 & $\begin{array}{l}\text { Shows no distinction in dealing } \\
\text { with school teachers }\end{array}$ & 3.26 & 1.00 & average \\
\hline 6 & Reduces teachers' anxiety & 3.95 & $\mathbf{0 . 9 8}$ & average \\
\hline 7 & $\begin{array}{l}\text { Assures equality when presenting } \\
\text { promotions and motives }\end{array}$ & 3.07 & 1,02 & average \\
\hline 8 & $\begin{array}{l}\text { Accept teachers thoughts and } \\
\text { suggestions }\end{array}$ & 3.83 & 1.06 & average \\
\hline 9 & $\begin{array}{l}\text { Deepens the spirit of group work } \\
\text { in teachers }\end{array}$ & 2,86 & 1.09 & average \\
\hline 10 & $\begin{array}{l}\text { Offers different means of } \\
\text { communicating with teachers }\end{array}$ & 3.62 & 0.63 & average \\
\hline 11 & $\begin{array}{l}\text { Exerts effort to solve different } \\
\text { problems among teachers }\end{array}$ & 3.22 & 0.99 & average \\
\hline 12 & $\begin{array}{l}\text { Emphasizes the importance } \\
\text { cooperation between old and } \\
\text { novice teachers }\end{array}$ & 3.26 & 1.22 & average \\
\hline \multicolumn{2}{|c|}{ The overall mean } & 3.45 & 0.95 & high \\
\hline
\end{tabular}

It is clear from the above table that Means of this dimension ranges between ( 2.86:4.07) and standard deviation (1.22), followed by item (6) " Reduces teachers' anxiety" with a mean (3.95) and standard deviation (0.98). Analysis of data also showed that item (9) " Deepens the spirit of group work in teachers" wieh a mean (2.86) and standard deviation (1.09). while item (7) " Assures equality 
when presenting promotions and motives" came before last as the mean is (3.07 and standard deviation (1.02).

Generally, the overall mean related to relations is (3.45) and standard deviation (0.95). This indicates that the level of educational supervisors use of leadership three dimensions theory in Ebry estate in Sultanate Oman was average in the relations dimension This result may be attributed to that the Educational supervisors has little concern with cooperation between old and novice teachers. Besides, they have no concern with the use of modern technology in the education process that concentrate on the student. This result may also be due to weak communication skills that the educational supervisor has. This result goes with those of Aysh (2012).

\section{Results related to the second question:}

Are there statistical significant difference in participants' evaluation of the level of the educational supervisors' use of the leadership three dimensions theory in Ebry estate in Sultanate Oman at 0.05 level that are due to the social type and qualifications variables?

" $t$ " test was used to identify the statistical significant differences between means of participants' evaluation of the level of the educational supervisors' use of the leadership three dimensions theory in Ebry estate in Sultanate Oman at 0.05 level of significance. Due to the social variable and the qualifications variable, and years of experience. One Way Anova was used and results were as follows: 


\section{Social Variable:}

(t-test) was used to identify the statistical significant differences between means of participants' evaluation of the level of the educational supervisors' use of the leadership three dimensions theory in Ebry estate in Sultanate Oman at 0.05 level of significance. The following table shows results related to this variable .

Table (6): t-test results of the mean differences among the participants responses to study fields related o the sociable variable

\begin{tabular}{|c|c|c|c|c|c|c|}
\hline no & Dimension & type & mean & SD & t-value & $\begin{array}{c}\text { Level of } \\
\text { significance }\end{array}$ \\
\hline \multirow[t]{2}{*}{ Dimension(1) } & \multirow{2}{*}{ Task } & male & 3.46 & 0.43 & \multirow{2}{*}{3.80} & \multirow{2}{*}{$0.00 *$} \\
\hline & & female & 3.80 & 0.33 & & \\
\hline \multirow{2}{*}{$\operatorname{Dimension}(2)$} & \multirow{2}{*}{ efficacy } & male & 3.25 & 0.60 & \multirow{2}{*}{1.29} & \multirow{2}{*}{1.20} \\
\hline & & female & 2.66 & 0.53 & & \\
\hline \multirow[t]{2}{*}{ Dimension(3) } & \multirow{2}{*}{ relations } & males & 3.35 & 0.51 & \multirow{2}{*}{0.12} & \multirow{2}{*}{0.91} \\
\hline & & female & 3.03 & 0.52 & & \\
\hline \multirow[t]{2}{*}{ Total mean } & \multirow{2}{*}{ general } & males & 3.65 & 0.35 & \multirow{2}{*}{1.91} & \multirow{2}{*}{0.07} \\
\hline & & female & 3.80 & $\mathbf{0 . 3 3}$ & & \\
\hline
\end{tabular}

*significant at 0.05 level

The above table shows no significant differences at 0.05 level in participants evaluation of the level of the educational supervisors' use of the leadership three dimensions theory in Ebry estate in Sultanate Oman attributed to the social variable in all dimensions of the study as t- value is (1.91) and level of significance is (0.07). This refers that males and females agree that educational supervisors' use of the leadership three dimensions theory in Ebry estate in Sultanate was average. This result was attributed to the birocratic ways they use and which is represented in their being rigid in using rules 
and instructions as imposed by the ministry of education. This result might be due to the tendency of the educational supervisors' use of traditional ways and this result does not cope with that of Aysh (2012).

\section{Qualifications:}

To indicate the differences between the means of the participants according to the qualifications variable, One way Anova was used.. The following table shows the results related to this variable.

Table (7): Results of One Way Anova for finding the significance of differences between means of scores of participants according to the qualifications variable

\begin{tabular}{|c|c|c|c|c|c|c|c|}
\hline no & Dimension & $\begin{array}{c}\text { Source of } \\
\text { variance }\end{array}$ & $\begin{array}{l}\text { Sum of } \\
\text { squres }\end{array}$ & $\begin{array}{l}\text { Degree } \\
\text { of } \\
\text { freedom }\end{array}$ & $\begin{array}{l}\text { Mean } \\
\text { of } \\
\text { squres }\end{array}$ & $F^{\prime \prime \prime \prime}$ & $\begin{array}{c}\text { Level of } \\
\text { significance }\end{array}$ \\
\hline \multirow{3}{*}{ Dimension(1) } & \multirow{3}{*}{ Task } & $\begin{array}{c}\text { Between } \\
\text { groups }\end{array}$ & 0.18 & 2 & \multirow{2}{*}{$\begin{array}{l}0.071 \\
0.191\end{array}$} & \multirow{3}{*}{0.63} & \multirow{3}{*}{0.56} \\
\hline & & $\begin{array}{l}\text { Within } \\
\text { groups }\end{array}$ & 17.20 & 144 & & & \\
\hline & & total & 17.15 & 150 & & & \\
\hline \multirow{3}{*}{$\operatorname{Dimension}(2)$} & \multirow{3}{*}{ efficacy } & $\begin{array}{c}\text { Between } \\
\text { groups }\end{array}$ & 1.75 & 2 & \multirow{3}{*}{0.801} & \multirow{3}{*}{2.60} & \multirow{3}{*}{0.08} \\
\hline & & $\begin{array}{l}\text { Within } \\
\text { groups }\end{array}$ & 2.66 & 0.53 & & & \\
\hline & & total & 47.44 & 150 & & & \\
\hline \multirow{3}{*}{ Dimension(3) } & \multirow{3}{*}{ relations } & $\begin{array}{l}\text { Bet. } \\
\text { groups }\end{array}$ & 0.25 & 2 & \multirow{3}{*}{0.109} & \multirow{3}{*}{0.46} & \multirow{3}{*}{0.67} \\
\hline & & $\begin{array}{l}\text { Within } \\
\text { groups }\end{array}$ & 36.16 & 148 & & & \\
\hline & & total & 37.33 & 150 & & & \\
\hline \multirow{3}{*}{ Total mean } & \multirow{3}{*}{ general } & $\begin{array}{c}\text { Bet. } \\
\text { groups }\end{array}$ & 0.28 & 2 & \multirow[t]{3}{*}{0.135} & \multirow{3}{*}{1.47} & \multirow{3}{*}{0.31} \\
\hline & & $\begin{array}{l}\text { Within } \\
\text { groups }\end{array}$ & 17.00 & 148 & & & \\
\hline & & total & 19.66 & 150 & & & \\
\hline
\end{tabular}


The above table shows that the calculated (F)of all dimensions is (1.47) and the level of significance is $(0.31)<$ 0.05 This means that there is no significant difference in educational supervisors' use level of the leadership three dimensions theory in Ebry estate in Sultanate Oman.

This might be due to the different qualifications variable in all dimensions as participants believe that educational supervisors are exposed to similar conditions in their work and are committed to tradirtional rules and instructions and they do not have the desire to share teachers and students in solving problems and taking decisions depending on their experiences and skills. This result contradicts that of Aysh (2012).

\section{Recommendations:}

In the light of the results obtained, the researchers recommend the following:

- Reinforcing the teachers' role in taking decisions related to the educational process and compelling the educational supervisors to take into consideration the teachers' view points when taking decisions.

- Paying attention to old teachers to invest their experience, improve their performance, and encourage them to cooperate with novice teachers.

- Increasing cooperation between supervisors and teachers when planning administrative and technical tasks.

- Reducing the use of the berocratic pattern especially in class visits

- Encouraging supervisors to use modern technology in their different supervision tasks 


\section{References}

- Aysh, Ahmed (2012). Educational supervisors 'practice of Redden's Leadership three dimensions theory: A study conducted on Ghoth Agency in Jordan. The education Journal. Kuwait University,102(1),309-320.

- Kanaan, Nowaf (1999).Administrative Leadership. Riyadh: Science House.

- Alghafary, Khamis bin Rashed. (2012).Level of Islamic education supervisors' practice of human relations in the supervision process from the teachers' point of view in Sultanate Oman, Unpublished MA thesis, Faculty of Education, Sultan Kbos University, Maskat : Sultanate Oman.

- Alfryhat,Ghalib Abdel Moaty (2016). Administration and Educational leadership. Oman: Digla Publishing House.

- Diwany. Kamal Slim. (2014).Educational Supervision: concepts and Horizons. Oman: printing and publishing Raya House

- Alrahby, younis bin Marhoon \& brahim Hosam Eldin Al Sayed Mohamed.(2019).The extent of private schools directors use of Reddin's theory dimensions and its relation to the creative behavior of teachers in Maskat Governorate in Sultanate Oman. Arabic Studies in Education and Psychology. Arab Education Association, No.116,213-246.

- Alenzy, Meshal bin Soliman (2017). Level of educational supervisors' Use of the creative leadership in Riyadh. Journal of Tabuk University of Social and Human Sciences. Tabuk University, No, 1. 21-48.

- Al Helw, ghassan Hussein (2009). Level of educational supervisors' Use of the Supervision patterns in 
Secondary schools in Palestine. Journal of Educational and Psychological Sciences. Albahreen University, 19(3),167-196.

- Alabidani, Khloud bint Ahmed bin Amer,(2020). Educational Supervisors' Application of Transformative Leadership in Sultanate Oman: an analytical and descriptive study. Journal of Educational and Psychological Sciences. The National Center of research, Ghazza, 4(11),67-80.

- Meskin, Abdulla (2015). Leadership behavior of educational supervisors (inspectors) in dealing with teachers: a pilot study of primary education inspectors in Mistghanem eastate. Journal of Educational and Psychological Sciences. Kasedy Merbah University. No.15,1-16

- Alzaidy, Ahmed Bin Mohamed.(2015). Transformative leadership behavior of Education offices directors in Gedda and its relation to the organization on confidence of educational supervisors. Faculty of Education Journal, Assiut University.31(5),168-242.

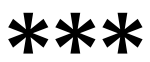

